\title{
PERTUMBUHAN DAN HASIL JAMUR TIRAM PUTIH PADA BEBERAPA BAHAN MEDIA PEMBIBITAN
}

\author{
The Growth and Yield of White Oyster Mushroom on Some Substrats of Seedling \\ Medium
}

\author{
Titik Suryani $^{1}$ dan Hilda Carolina ${ }^{2}$ \\ ${ }^{1}$ Dosen Pendidikan Biologi, FKIP, Universitas Muhammadiyah Surakarta, \\ ${ }^{2}$ Alumni Prodi Agronomi, FPN, Univ. Wangsa Manggala, Yogjakarta \\ ts169@ums.ac.id/suryanit@ymail.com
}

\begin{abstract}
Penelitian ini bertujuan untuk mengetahui jenis media pembibitan yang mampu mendukung peningkatan kualitas bibit jamur tiram putih lebih baik, dan mengetahui pengaruh macam media bibit terhadap pertumbuhan dan hasil jamur tiram putih. Penelitian ini dilaksanakan di Ngemplak, Nanggulan, Kulon Progo, Daerah Istimewa Jogjakarta dengan ketinggian tempat 300 m dpl. Rancangan yang digunakan adalah faktor tunggal macam media pembibitan, dalam Rancangan Acak Lengkap (RAL), terdiri atas 4 perlakuan, yaitu : media bibit dengan serbuk kayu sengon, biji sorghum, biji jagung, dan biji padi dengan 3 ulangan. Hasil penelitian menunjukkan bahwa media bibit biji sorghum dan biji jagung mampu mendukung peningkatan kualitas bibit jamur tiram putih yang lebih baik dibandingkan dari media biji padi dan serbuk gergaji sengon. Bibit pada media substrat biji sorghum, jagung, padi dan serbuk gergaji sengon memberikan pertumbuhan jamur tiram putih yang sama. Hasil jamur tiram putih lebih baik pada bibit dengan media substrat biji sorghum, jagung, padi berturut - turut.
\end{abstract}

Kata kunci: Jamur tiram putih (Pleurotus ostreatus), media pembibitan (serbuk gergajian sengon, biji sorghum, biji jagung, biji padi).

\begin{abstract}
The goal of this experiment was to know ability improving quality of white oyster mushroom seed and to know the effect of kind seedling medium on the growth and yield of white oyster mushroom. The experiment has been done in Ngemplak, Nanggulan, Kulon Progo, Jogjakarta Special Territory, at height of $300 \mathrm{~m}$ the sea surface level,. The experimental design used the single factor kind of seedling medium arranged Completely Randomized Design ( CRD ), that shown by four treatments that were seedling medium with sengon sawdust, sorghum seed, corn seed, rice seed repetited three times. The experiment result showed that sorghum and corn seed medium were ability to increasing quality of white oyster mushroom seed better than of rice seed and sengon sawdust. The substrate medium of sorghum seed, corn seed, rice seed and sengon sawdust gave the same growth of white oyster mushroom. The yield of white oyster mushroom was better on the sorghum seed, corn seed, rice seed substrate medium respectively.
\end{abstract}

Keywords: White Oyster Mushroom (Pleurotus ostreatus), Seedling Medium (sengon sawdust, sorghum, corn, rice)

\section{PENDAHULUAN}

Jamur tiram putih adalah salah satu jamur edibel yang hidup pada kayu yang lapuk, sebagai salah satu sumber hayati dan sumber protein nabati di samping kacang-kacangan, dan digemari oleh masyarakat ,. Jamur tiram putih mengandung vitamin B1, B2, C, niasin, biotin, serta mineral $\mathrm{K}, \mathrm{P}, \mathrm{Ca}, \mathrm{Na}, \mathrm{Mg}$, dan $\mathrm{Cu}$ (Reginawati, 1999). Kandungan Gizi
Jamur Tiram (100 gr) meliputi : protein $30,4 \%$, karbohidrat 56,6\%, lemak 2,2\%, kalsium $314 \mathrm{mg}$, fosfor $717 \mathrm{mg}$, natrium $837 \mathrm{mg}$, besi $18,2 \mathrm{mg}$, niacin $77,2 \mathrm{mg}$, riboflavin $4,95 \mathrm{mg}$ dan thiamin $0,20 \mathrm{mg}($ Djarijah,2001).

Nilai ekonomis jamur tiram putih terus meningkat dan prospeknya sebagai salah satu komiditas ekspor non migas. Indonesia baru mampu 
memasok 0,9\% kebutuhan jamur dunia, padahal budidaya jamur sangat mudah dikembangkan didalam negeri, apalagi lahan yang dibutuhkan tidak luas untuk itu di Indonesiajuga tersedia. Berdasarkan data dari Ditjen Hortikultura,tahun 2010 Pemda Jember, mengekspor jamur tiram putih ke jepang mencapai 5 kontainer, tiap kontainer berisi 16 ton. (Anonim, 2014).

Sejalan dengan permintaan pasar dan potensi jamur tiram yang tinggi dimanfaatkan sebagai bahan pangan dan sebagai obat. Indonesia termasuk salah satu negara yang berpeluang untuk mengekspor jamur ke Amerika, Kanada, Jerman, Jepang, Hongkong, Belgia, Inggris, Belanda dan Italia. Beberapa faktor yang harus ditingkatkan untuk menembus pasar baik dalam maupun luar negeri adalah optimalisasi kultur teknis dan perlakuan pasca panen yang menjamin keseragaman jamur (Anonim, 2004).

Selain itu usaha budidaya jamur tiram putih dianggap sebagai bisnis yang menguntungkan karena waktu panen cepat sekitar 3 bulan, sehingga modalnya juga cepat kembali. Bahan baku untuk budidaya jamur tiram putih mudah didapat dan lahan untuk budidaya jamur tiram tidak terlalu luas (Agus dkk, 2001). Keberhasilan budidaya jamur tiram putih ditentukan oleh kualitas bibit, proses budidaya, temperatur dan kelembaban lingkungan yang mendukung (Cahyana, 2005).

Pembibitanjamurtiram putihbiasanya menggunakan media kombinasi serbuk gergaji sebagai media dasar dan beberapa campuran seperti bekatul, sementara itu masih banyak jenis media lain yang cukup potensial ditinjau dari kandungan nutrisinya bagi jamur tiram putih, karena itu perlu pengujian perlakuan beberapa jenis media bibit, apakah dengan media yang berbeda kualitas bibit jamur tiram putih yang diperoleh masih cukup baik atau bahkan justru lebih baik dibanding dengan bibit yang dihasilkan dengan menggunakan media standar.

Media bibit merupakan salah satu faktor penting penentu keberhasilan dan kualitas jamur, dengan media bibit yang bahannya lebih baik atau diperkaya dengan biji-bijian, nutrisi yang ada pada biji-bijian akan mudah diserap oleh jamur dari pada media serbuk kayu serta akan dihasilkan bibit jamur yang lebih baik.Media bibit jamur dapat digunakan berbagai macam bahan. Beberapa bahan media bibit jamur yang dapat digunakan di antaranya biji - bijian, serbuk kayu, kotoran ternak, dan bahan organik lainnya. Setiap jenis jamur mempunyai spesifikasi pertumbuhan yang khas pada setiap bahan media tanam, sehingga tidak setiap bahan media tanam cocok digunakan untuk pertumbuhan bibit semua jenis jamur (Gunawan, 2005).

Keuntungan penggunaan media bibit dari biji - bijian yaitu miselium tumbuh dengan cepat, namun media seperti ini kaya akan zat gizi sehingga kerusakan yang disebabkan oleh kontaminan juga mudah terjadi (Gunawan, 2005). Biji serealia seperti sorghum, jagung, padi dapat digunakan sebagai bahan untuk media bibit jamur tiram dengan kualitas biji baik. Biji yang pecah, terkena penyakit, dan tercampur dengan kotoran atau biji lain jangan dipilih untuk media (Gunawan, 2005).

Biji sorghum dapat digunakan sebagai bahan makanan yang banyak mengandung karbohidrat juga dapat dimanfaatkan sebagai pakan ternak. Nilai gizi biji sorghum mengandung karbohidrat $(83 \%)$, protein $(11,0 \%)$, lemak $(3,3 \%)$, serat $(2,1 \%)$, kandungan lain (11\%) (Nurmala, 1998).Biji jagung dapat digunakan sebagai media bibit jamur karena mempunyai komposisi kimia antara lain karbohidrat $(68,0 \%)$, 
protein $(10 \%)$, lemak $(5,0 \%)$, serat $(2,0 \%)$, kandungan lain (11\%) (Nurmala, 1998). Biji padi mempunyai nilai gizi yang cukup memadai antara lain karbohidrat $(76,0 \%)$, protein $(8,0 \%)$, lemak $(0,8 \%)$, serat $(1,0 \%)$, kandungan lain (11,1\%) (Nurmala, 1998).

Bahan untuk media bibit jamur tiram: bekatul diperlukan sebagai sumber nutrisi dan sumber karbohidrat, karbon nitrogen dan vitamin B kompleks. mengandung air $15 \%$, protein $14,5 \%, \mathrm{~N}$ $48,7 \%$, serat kasar, $7,4 \%$, lemak7,4\% dan abu 7,0\%. (Lubis, 1992).l Bekatul yang digunakan dapat berasal dari berbagai jenis padi. Bekatul sebaiknya dipilih yang masih baru, belum tengik dan tidak rusak (Cahyana, 2002). Karbon sebagai sumber energi utama sekaligus sebagai unsur pertumbuhan, nitrogen untuk pertumbuhan miselium dan membangun enzim - enzim yang disimpan dalam tubuhnya, vitamin berfungsi memacu pertumbuhan tubuh buah (Soenanto, 2000). Kapur berfungsi menjaga keasaman media, agar mendekati suasana netral dan sebagai sumber mineral (Cahyana, 2002). Pembibitan jamur tiram memerlukan kondisi lingkungan dengan temperatur untuk pembentukan miselium adalah 22 $-28^{\circ} \mathrm{C}$, dengan kelembaban $60-0 \%$. Pada pembibitan tidak diperlukan cahaya, miselium akan tumbuh pada keadaan gelap, oleh karena itu selama inkubasi diletakkan ditempat yang gelap (Anonim, 1999).

Media produksi bagi pertumbuhan jamur tiram sebaiknya dibuat menyerupai kondisi tempat tumbuh jamur tiram dialam. Bahan baku yang digunakan sebagai media dalam budidaya jamur tiram dapat berupa batang kayu gelondongan atau dengan serbuk gergaji (Cahyana, 2002). Serbuk gergaji kayu sebagai bahan utama merupakan media tumbuh jamur kayu karena mengandung selulosa, lignin, karbohidrat, dan serat (Suriawira, 2002). Serbuk gergaji kayu sengon memenuhi syarat untuk media tumbuh jamur tiram karena mengandung selulosa tinggi, lignin rendah, tidak bergetah, mudah menyerap dan menyimpan air, serta proses pengeringan dan pengomposannya cepat (Atmosuseno, 1998). Persentase komponen kimia kayu sengon adalah selulosa $(49,4 \%)$, lignin $(26,8 \%)$, pentosa $(15,6 \%)$ (Martawijaya, 1981). Kapur berfungsi menjaga $\mathrm{pH}$ media, agar mendekati suasana netral dan sebagai sumber mineral.Gips digunakan sebagai sumber kalsium dan sebagai bahan tanam untuk memperkokoh media tanam dalam polibag sehingga tidak mudah hancur atau rusak (Cahyana, 2002).

Budidaya jamur tiram putih memerlukan kondisi lingkungan yang sesuai. Faktor lingkungan yang mempengaruhi pertumbuhan jamur tiram adalah sumber nutrisi, suhu, udara, temperatur, kelembaban, cahaya, air. Jamur tiram putih sangat baik dibudidayakan pada ketinggian 400-800 mdpl. Namun tidak tertutup kemungkinan untuk tumbuh dan dibudidayakan di daerah dataran rendah. Temperatur yang cocok untuk budidaya jamur tiram putih adalah $22-28{ }^{\circ} \mathrm{C}$ dengan kelembaban $60-90 \%$, sedangkan temperatur pada pembentukan tubuh buah berkisar $15-30{ }^{\circ} \mathrm{C}$ dengan kelembaban $\quad 80-90 \%$. Apabila suhu terlalu tinggi, sedangkan kelembaban terlalu rendah calon tubuh buah akan kering dan mati (Cahyana 2002). Jamur tiram sangat sensitif terhadap cahaya matahari langsung dan tidak cocok dibudidayakan didaerah yang sangat panas. Oleh karena itu rumah jamur tiram dibuat sedemikian tertutup (Soenanto, 2000). Sedangkan sinar tidak langsung yang bersifat menyebar diperlukan selama masa pertumbuhan tubuh buah. Jamur membutuhkan sirkulasi udara segar untuk pertumbuhannya sehingga 
diberi ventilasi agar aliran udara bisa berjalan lancar (Anonim, 1999). Waktu yang diperlukan untuk tiap stadium atau tingkatan daur hidup bervariasi, tergantung pada bentuk dan sifat media tempat tumbuh jamur tiram, lingkungan yang mendukung, misalnya lingkungan kimia ( $\mathrm{pH}$, kadar air), dan lingkungan biologis (kehadiran jasad lain, misalnya bakteri atau jamur liar), serta jenis jamur tiram (Suriawiria, 2002). Dalam keadaan normal, waktu yang diperlukan dari perkecambahan spora sampai terbentuk tubuh buah rata-rata 1-2 bulan (Suriawiria, 2002).

Tujuan Penelitian untuk Mengetahui jenis media yang mampu mendukung peningkatan kualitas bibit jamur tiram putih yang lebih baik dari media standar dan mengetahui pengaruh macam media bibit terhadap pertumbuhan dan hasil jamur tiram putih. Hasil penelitian ini diharapkan dapat memberikan informasi mengenai media bibit yang lebih baik dari media bibit standar bagi pertumbuhan dan hasil jamur tiram putih.

\section{METODE PENELITIAN}

Penelitian ini dilakukan di Ngemplak, Nanggulan, Kulon Progo, Yogyakarta yang mempunyai ketinggian tempat 300 m dpl. Bahan : bibit jamur tiram putih $\left(\mathrm{F}_{2}\right)$, serbuk gergaji kayu sengon, biji sorghum, biji jagung, biji padi, bekatul, kapur $\left(\mathrm{CaCO}_{3}\right)$, gips $\left(\mathrm{CuSO}_{4}\right)$, air, alkohol $70 \%$, kapas.alat : jarum ose, botol, polybag, timbangan, lampu spritus, ayakan, alat pengepres, alat sterilisasi (autoklaf dan ruang sterilisasi), termometer ruang, hygrometer, jangka sorong, mistar, sprayer. Metode yang digunakan adalah percobaan faktor tunggal yang disusun dalam Rancangan Acak Lengkap (RAL), yang terdiri atas 4 perlakuan. Setiap perlakuan diulang 3 kali masing-masing terdiri atas 6 polybag dan diambil 4 polybag secara acak sebagai sampel sehingga diperoleh seluruhnya $4 \times 3 \times 6$ $=72$ polybag.

Faktor perlakuan sebagai berikut: A(pembibitan pada media bibit serbuk kayu sengon), $\mathrm{B}$ (pembibitan pada media bibit biji sorghum), C(pembibitan pada media bibit biji jagung), $\mathrm{D}$ (pembibitan pada media bibit biji padi ). Bibit tersebut diatas diinokulasikan pada media dasar serbuk gergaji kayu sengon untuk mengetahui perbandingan dari masing-masing perlakuan. Komposisi bahan media tumbuh (produksi) yang digunakan adalah : Serbuk gergajian kayu sengon 92,5\%, Bekatul 5\%, Gips $1,5 \%$,Kapur 1\%, kadar air media 45 - $65 \%$.

\section{Pelaksanaan Penelitian}

a. Media Bibit

1) Biji direndam dalam air selama 2 jam. Dibuang kotoran dan biji yang mengapung. Untuk media serbuk gergaji kayu sengon diayak untuk menghilangkan potongan kayu berukuran besar atau kotoran lain seperti kerikil, kemudian direndam untuk menghilangkan getah dan minyak yang terdapat pada kayu. Perendaman dilakukan pada kayu selama 12 jam. Setelah direndam serbuk kayu ditiriskan.

2) Biji ditiriskan lalu dimasak dengan air sampai biji merekah pada satu titik (direbus $1 / 2$ matang). Biji yang sudah masak ditiriskan.

3) Media dicampur dengan bahan-bahan lain sampai merata sesuai dengan perlakuan yang ditentukan. 
Tabel 1. Komposisi bahan media bibit untuk tiap perlakuan.

\begin{tabular}{cl}
\hline Perlakuan & \multicolumn{1}{c}{ Komposisi Bahan Media Bibit (100\%) } \\
\hline A & $\begin{array}{l}\text { Serbuk kayu sengon }(88 \%)+\text { Bekatul }(10 \%)+\text { Kapur }(1 \%)+\text { gips } \\
(1 \%)+\text { Air (Sampai diperoleh kadar air media 45\%) }\end{array}$ \\
B & Biji sorhgum $(98 \%)+$ kapur $(1 \%)+$ gips $(1 \%)$ \\
C & Biji jagung $(98 \%)+$ kapur $(1 \%)+$ gips $(1 \%)$ \\
D & Biji Padi $(98 \%)+$ kapur $(1 \%)+$ gips $(1 \%)$ \\
\hline
\end{tabular}

4) Media bibit yang telah tercampur dimasukkan dalam botol warna putih dengan diameter $6 \mathrm{~cm}$, tinggi $20 \mathrm{~cm}$ dan bobot tiap botol seberat $250 \mathrm{~g}$ tanpa dipadatkan. Botol ditutup dengan kapas dan ditutup lagi dengan plastik.

5) Media bibit disterilkan dengan menggunakan autoklaf pada suhu $121 \stackrel{\circ}{ } \mathrm{C}$ selama 60 menit. Media didinginkan selama 12 jam sebelum dilakukan inokulasi.

6) Alat inokulasi (jarum ose) disterilkan dengan menggunakan alkohol dan dilakukan pembakaran dengan lampu spiritus.

7) $\mathrm{F}_{2}$ diambil dengan alat inokulasi (jarum ose) secara aseptis dan dimasukkan ke dalam media bibit.

8) Media bibit dalam botol ditutup rapat dengan kapas.

9) Media bibit diinkubasikan pada suhu $\pm 28{ }^{\circ} \mathrm{C}$ sampai seluruh media penuh dengan miselium jamur yang berwarna putih, yaitu selama 4 minggu.

b. Media Tumbuh (media produksi) Jamur Tiram

1) Persiapan media tanam: Serbuk gergaji kayu sengon diayak untuk menghilangkan potongan kayu berukuran besar, kerikil.

2) Pencampuran : media tanam dicampur sampai merata dengan komposisi (100\%) yang ditentukan yaitu: serbuk gergajian kayu sengon 92,5\%, Bekatul 5\%, Gips 1,5\%, Kapur1\%, kadar air media 45 $-65 \%$

3) Pengomposan: setelah bahan tercampur rata dilakukan pengomposan dengan cara membumbun campuran tersebut, kemudian ditutup rapat dengan menggunakan plastik selama 7 hari, dengan tingkat keasaman $(\mathrm{pH}) \pm 7$.

4) Pembungkusan pembungkusan dilakukan dengan cara memasukkan media ke dalam kantong plastik putih tahan panas (PP) ukuran $20 \times 30 \mathrm{~cm}$ kemudian media dipadatkan. Media yang telah dipadatkan ditutup bagian atasnya dengan memasukkan cincin pralon dan disumbat dengan kapas, sehingga bungkusan media akan meyerupai botol. Bobot setiap polybag $1 \mathrm{~kg}$.

5) Sterilisasi :media dipolybag selanjutnya disterilisasi pada ruang sterilisasi, dengan dipanaskan uap air pada suhu 80 - $90^{\circ} \mathrm{C}$ selama 8 jam. 
6) Pendinginan :media yang telah disterilisasi didinginkan selama 12 jam sebelum dilakukan inokulasi.

7) Inokulasi :dibuat lubang sedalam $2 \mathrm{~cm}$ pada bagian tengah media dengan menggunakan stik kayu yang disterilkan. Bibit sebanyak 1 sendok makan dimasukkan ke polybag secara aseptis.

8) Inkubasi : media yang telah diisi bibit disimpan dalam ruangan yang bersuhu \pm 28 ${ }^{\circ} \mathrm{C}$ hingga seluruh media ditumbuhi oleh miselium berwarna putih.

9) Saat pembentukan calon tubuh buah : media yang telah dipenuhi miselium dibuka bagian atasnya dan dilepas cincin pralon, agar calon tubuh buah jamur dapat tumbuh dengan baik. Dengan suhu ruang sekitar $23{ }^{\circ} \mathrm{C}$ dengan kelembaban $90 \%$.

10) Pemeliharaan :untuk menjaga kelembaban disiram 3 kali sehari dengan menggunakan sprayer.

11) Pemanenan : panen dilakukan setelah pertumbuhan jamur mencapai tingkat yang optimal, yaitu tubuhbuah telah membuka secara maksimal. Pemanenan dilakukan dengan cara mencabut jamur dari media tanam secara hati-hati.

Pengamatan : dilakukan pada sampel yang terdiri dari 3 sampel. Parameter pengamatan meliputi :

a. Pengamatan Bibit:

1) Panjang miselium bibit (centimeter),Pengamatan dilakukan 7 hari setelah inokulasi dengan mengukur panjang miselium menggunakan mistar. Pengukuran dilakukan dari permukaan media sampai kedalaman tertentu pada pertumbuhan miselium paling panjang. Pengamatan dilakukan pada hari ke 7, 14, 21 dan 28. 2.Sifat miselia : (tipis, sedang, tebal), Pengamatan dilakukan dengan melihat ketebalan miselium.

\section{b. Pengamatan produksi}

1) Panjang miselium pada media tumbuh (centimeter) :pengamatan dilakukan 7 hari setelah inokulasi dengan mengukur panjang miselium menggunakan mistar. Pengukuran dilakukan dari permukaan media sampai kedalaman tertentu pada pertumbuhan miselium paling panjang. Pengamatan dilakukan pada hari ke 7, 14, 21 dan 28.

2) Saat pemenuhan miselium (hari): pengamatan dilakukan sejak inokulasi sampai miselium tumbuh memenuhi polybag.

3) Saat pembentukan calon tubuh buah (hari) : pengamatan dilakukan setelah inokulasi sampai terbentuk calon tubuh buah yang pertama kali. Dilakukan perhitungan lama hari pembentukan calon tubuh buah yang tumbuh pada media. Pembentukan calon tubuh buah mulai dihitung ketika muncul calon tubuh buah kecil (primordia) berukuran $\pm 1 \mathrm{~cm}$.

4) Jumlah tubuh buah tiap panen dan total panen: Pengamatan dilakukan 
dengan menghitung jumlah tubuh buah tiap kali panen dan total jumlah tubuh buah dijumlahkan pada akhir panen.

5) Diameter tubuh buah (centimeter) :Pengamatan dilakukan dengan mengukur diameter badan buah pada bagian bawah tudung jamur setiap kali panen.

6) Berat segar tubuh buah tiap panen dan total panen (gram) :Pengamatan dilakukan dengan menimbang tubuh buah tiap kali panen dan total bobot segar jamur dijumlahkan pada akhir panen.

7) Umur panen (hari) :Dihitung sejak pemenuhan miselium sampai panen ke - 1, 2, 3, 4, 5, 6.

8) Lama masa panen (hari) :Dihitung lama hari mulai panen pertama sampai terakhir. Pemanenan diakhiri setelah tidak lagi tumbuh tubuh buah jamur tiram (hasil sangat menurun).

\section{Analisis Data}

Data dianalisis dengan sidik ragam pada taraf $5 \%$ untuk mengetahui adanya beda nyata dari perlakuan yang diamati, kalau ada beda nyata dilanjutkan dengan uji Duncan's Multiple Range Test (DMRT) pada jenjang $5 \%$.

\section{HASIL DAN PEMBAHASAN}

\section{Hasil Analisis}

Hasil analisis meliputi variabel pertumbuhan terdiri dari panjang miselium media bibit, sifat miselia bibit, panjang miselium media produksi, saat pemenuhan miselium, saat pembentukan tubuh buah, sedangkan variabel hasil meliputi jumlah tubuh buah tiap panen dan total panen, diameter tubuh buah, berat segar tubuh buah tiap panen dan total panen, umur tiap panen, lama masa panen.

\section{a. Variabel pertumbuhan miselium pada media bibit \\ 1) Panjang miselium bibit ( $\mathrm{cm})$ dan sifat miselium bibit \\ Purata panjang miselium bibit yang dilakukan pada umur 7, 14, 21, 28 hari setelah inokulasi dan sifat miselium bibit disajikan dalam tabel 2.}

Tabel 2. Purata panjang miselium bibit $(\mathrm{cm})$ dan sifat miselium bibit setelah inokulasi pada 4 bahan media pembibitan jamur

\begin{tabular}{|c|c|c|c|c|c|}
\hline \multirow{2}{*}{ Perlakuan } & \multicolumn{4}{|c|}{ Umur (hari) } & \multirow{2}{*}{$\begin{array}{c}\text { Sifat } \\
\text { Miselia }\end{array}$} \\
\hline & 7 & 14 & 21 & 28 & \\
\hline A & $2,50 \mathrm{~b}$ & $6,33 a$ & $10,50 a$ & $15,33 a$ & Tipis \\
\hline B & $5,00 \mathrm{a}$ & $7,83 a$ & $11,83 a$ & $15,67 \mathrm{a}$ & Tebal \\
\hline C & $4,83 a$ & $7,17 a$ & $11,50 \mathrm{a}$ & $15,33 a$ & Tebal \\
\hline D & $5,00 \mathrm{a}$ & $6,67 a$ & $10,50 \mathrm{a}$ & $15,67 \mathrm{a}$ & Sedang \\
\hline
\end{tabular}

Keterangan:Angka purata yang diikuti huruf sama pada kolom sama menunjukkan tidak ada beda nyata menurut DMRT taraf nyata 5\%

A: Pembibitan pada media bibit serbuk kayu sengon

B: Pembibitan pada media bibit biji sorghum

C: Pembibitan pada media bibit biji jagung

D: Pembibitan pada media bibit biji padi 
Hasil sidik ragam panjang miselium bibit menunjukkan ada beda nyata pada hari ke 7 setelah inokulasi, sedangkan panjang miselium pada hari ke - 14, 21 dan 28 tidak ada beda nyata. (Tabel 2). Sifat miselium bibit lebih tebal pada media biji sorghum dan biji jagung, pada media biji padi sedang dan media serbuk gergaji kayu sengon tipis (Tabel 2).

b. Variabel pertumbuhan miselium pada media tumbuh jamur

1) Panjang miselium media tumbuh jamur $(\mathrm{cm})$

Purata panjang miselium media tumbuh jamur yang dilakukan pada umur 7, 14, 21 dan 28 hari setelah inokulasi disajikan dalam tabel 3 .

Tabel 3. Purata panjang miselium pada media tumbuh jamur setelah inokulasi (cm) pada 4 bahan media pembibitan jamur

\begin{tabular}{ccccc}
\hline \multirow{2}{*}{ Perlakuan } & \multicolumn{4}{c}{ Umur (hari) } \\
\cline { 2 - 5 } & $\mathbf{7}$ & $\mathbf{1 4}$ & $\mathbf{2 1}$ & $\mathbf{2 8}$ \\
\hline A & $0,83 \mathrm{~b}$ & $9,42 \mathrm{c}$ & $16,42 \mathrm{~b}$ & $21,54 \mathrm{a}$ \\
B & $4,42 \mathrm{a}$ & $11,71 \mathrm{a}$ & $18,33 \mathrm{a}$ & $22,00 \mathrm{a}$ \\
C & $3,50 \mathrm{a}$ & $11,33 \mathrm{ab}$ & $18,00 \mathrm{a}$ & $22,00 \mathrm{a}$ \\
D & $3,21 \mathrm{a}$ & $10,83 \mathrm{~b}$ & $16,92 \mathrm{~b}$ & $21,71 \mathrm{a}$ \\
\hline
\end{tabular}

Keterangan:Angka purata yang diikuti huruf sama pada kolom sama menunjukkan tidak ada beda nyata menurut DMRT taraf nyata $5 \%$

Hasil sidik ragam panjang miselium pada media tumbuh menunjukkan ada beda nyata pada hari ke $7,14,21$, sedangkan panjang miselium pada hari ke - 28 tidak ada beda nyata.
2) Saat pemenuhan miselium dan saat pembentukan calon tubuh buah (hari)

Purata saat pemenuhan miselium dan saat pembentukan tubuh buah disajikan pada tabel 4 .

Tabel 4. Purata saat pemenuhan miselium dan pembentukan calon tubuh buah pada 4 bahan media pembibitan jamur (hari)

\begin{tabular}{ccc}
\hline Perlakuan & $\begin{array}{c}\text { Saat pemenuhan mise- } \\
\text { lium }\end{array}$ & $\begin{array}{c}\text { Saat pembentukan calon } \\
\text { tubuh buah }\end{array}$ \\
\hline A & $32,17 \mathrm{a}$ & $42,33 \mathrm{a}$ \\
B & $27,50 \mathrm{a}$ & $32,25 \mathrm{c}$ \\
C & $27,83 \mathrm{a}$ & $34,08 \mathrm{bc}$ \\
D & $29,83 \mathrm{a}$ & $36,75 \mathrm{~b}$ \\
\hline
\end{tabular}

Keterangan : Angka purata yang diikuti huruf sama pada kolom sama menunjukkan tidak ada beda nyata menurut DMRT taraf nyata 5\%
A : Pembibitan pada media bibit serbuk kayu sengon
B : Pembibitan pada media bibit biji sorghum
C : Pembibitan pada media bibit biji jagung
D : Pembibitan pada media bibit biji padi 
Hasil sidik ragam saat pemenuhan miselium menunjukkan tidak ada beda nyata. (Tabel 4).Saat pembentukan tubuh buah menunjukkan beda nyata. Saat pembentukan calon tubuh buah pada perlakuan B, C, dan $\mathrm{D}$ berbeda nyata dengan perlakuan A (Tabel 4).

\section{c. Variabel Hasil}

1) Jumlah tubuh buah tiap panen dan total panen (buah)

Purata jumlah tubuh buah tiap panen dan total panen disajikan pada tabel 5 .

Tabel 5. Purata jumlah tubuh buah tiap panen \& total panen pada 4 bahan media pembibitan jamur

\begin{tabular}{|c|c|c|c|c|c|c|c|}
\hline \multirow{2}{*}{ Perlakuan } & \multicolumn{6}{|c|}{ Pengamatan Panen $\mathrm{Ke}$ - } & \multirow{2}{*}{ Total } \\
\hline & 1 & 2 & 3 & 4 & 5 & 6 & \\
\hline $\mathbf{A}$ & $4,58 \mathrm{a}$ & $5,50 a$ & $4,08 \mathrm{a}$ & $4,08 \mathrm{a}$ & $3,75 a$ & $4,33 a$ & $26,33 a$ \\
\hline B & $5,67 \mathrm{a}$ & $5,58 \mathrm{a}$ & $5,17 \mathrm{a}$ & $5,50 \mathrm{a}$ & $4,83 a$ & $3,42 \mathrm{a}$ & $30,17 \mathrm{a}$ \\
\hline C & $7,17 \mathrm{a}$ & $4,67 a$ & $5,08 \mathrm{a}$ & $5,00 \mathrm{a}$ & $4,17 \mathrm{a}$ & $3,83 a$ & $29,92 \mathrm{a}$ \\
\hline D & $7,33 a$ & $7,17 a$ & $6,33 a$ & 5,33a & $4,25 \mathrm{a}$ & $3,50 \mathrm{a}$ & $33,92 \mathrm{a}$ \\
\hline
\end{tabular}

Keterangan:Angka purata yang diikuti huruf sama pada kolom sama menunjukkan tidak ada beda nyata menurut DMRT taraf nyata 5\%

Hasil sidik ragam jumlah tubuh buah tiap panen dan total panen tidak ada beda nyata (Tabel 5).

A : Pembibitan pada media bibit serbuk kayu sengon

B : Pembibitan pada media bibit biji sorghum

$C$ : Pembibitan pada media bibit biji jagung

D : Pembibitan pada media bibit biji padi

2) Diameter tubuh buah $(\mathrm{cm})$

Purata diameter tubuh buah disajikan pada tabel 6 . Hasil sidik ragam diameter tubuh buah menunjukkan tidak ada beda nyata pada panen $1,2,3,4,5$ dan 6 .

Tabel 6. Purata diameter tubuh buah $(\mathrm{cm})$ pada 4 bahan media pembibitan

\begin{tabular}{ccccccc}
\hline \multirow{2}{*}{ Perlakuan } & \multicolumn{7}{c}{ Pengamata Panen Ke - } \\
\cline { 2 - 7 } & $\mathbf{1}$ & $\mathbf{2}$ & $\mathbf{3}$ & $\mathbf{4}$ & $\mathbf{5}$ & $\mathbf{6}$ \\
\hline A & $9,13 \mathrm{a}$ & $9,67 \mathrm{a}$ & $7,38 \mathrm{a}$ & $7,08 \mathrm{a}$ & $7,18 \mathrm{a}$ & $5,43 \mathrm{a}$ \\
B & $8,30 \mathrm{a}$ & $11,23 \mathrm{a}$ & $9,73 \mathrm{a}$ & $8,34 \mathrm{a}$ & $6,83 \mathrm{a}$ & $5,87 \mathrm{a}$ \\
C & $9,70 \mathrm{a}$ & $10,46 \mathrm{a}$ & $8,91 \mathrm{a}$ & $7,84 \mathrm{a}$ & $6,94 \mathrm{a}$ & $5,97 \mathrm{a}$ \\
D & $10,48 \mathrm{a}$ & $10,30 \mathrm{a}$ & $8,75 \mathrm{a}$ & $8,31 \mathrm{a}$ & $7,57 \mathrm{a}$ & $6,42 \mathrm{a}$ \\
\hline
\end{tabular}

Keterangan : Angka purata yang diikuti huruf sama pada kolom sama menunjukkan tidak ada beda nyata menurut DMRT taraf nyata 5\%

A : Pembibitan pada media bibit serbuk kayu sengon

B : Pembibitan pada media bibit biji sorghum

C : Pembibitan pada media bibit biji jagung

D : Pembibitan pada media bibit biji padi 
3) Berat segar tubuh buah tiap panen dan total panen $(\mathrm{g})$

Purata hasil pengamatan terhadap berat segar tubuh buah tiap panen dan total panen disajikan pada tabel 7.

Tabel 7. Purata berat segar tubuh buah tiap panen dan total panen (g) pada 4 bahan media pembibitan jamur

\begin{tabular}{|c|c|c|c|c|c|c|c|}
\hline \multirow{2}{*}{$\begin{array}{c}\text { Per- } \\
\text { lakuan }\end{array}$} & \multicolumn{6}{|c|}{ Pengamatan Panen Ke - } & \multirow{2}{*}{ Total } \\
\hline & 1 & 2 & 3 & 4 & 5 & 6 & \\
\hline A & $64,42 a$ & $73,92 b$ & $53,08 b$ & $43,33 b$ & $32,33 a$ & $23,08 \mathrm{a}$ & $290,17 b$ \\
\hline B & $61,33 a$ & $101,83 a$ & $74,92 \mathrm{a}$ & $57,33 a$ & $36,50 a$ & $24,67 a$ & $356,58 \mathrm{a}$ \\
\hline C & $79,83 a$ & $71,58 b$ & $73,42 a$ & $56,92 a$ & $35,25 a$ & $22,08 \mathrm{a}$ & $339,08 \mathrm{a}$ \\
\hline D & $76,50 \mathrm{a}$ & $74,58 \mathrm{~b}$ & $75,50 \mathrm{a}$ & $56,33 a$ & $34,33 a$ & $27,75 a$ & $345,00 \mathrm{a}$ \\
\hline
\end{tabular}

Keterangan : Angka purata yang diikuti huruf sama pada kolom sama menunjukkan tidak ada beda nyata menurut DMRT taraf nyata $5 \%$.

Hasil sidik ragam berat segar tubuh buah tiap panen dan total panen menunjukkan beda nyata pada panen ke -2 , 3, 4 dan total panen. Sedangkan pada panen ke 1, 5 dan 6 tidak beda nyata.
4) Umur panen dan lama masa panen (hari)

Purata umur panen dan lama masa panen disajikan pada tabel 8 .

Tabel 8. Purata umur panen dan lama masa panen (hari) pada 4 bahan media pembibitan jamur

\begin{tabular}{|c|c|c|c|c|c|c|c|}
\hline \multirow{2}{*}{ Perlakuan } & \multicolumn{6}{|c|}{ Umur panen (pengamatan panen ke -) } & \multirow{2}{*}{$\begin{array}{c}\text { Lama Masa } \\
\text { Panen }\end{array}$} \\
\hline & 1 & 2 & 3 & 4 & 5 & 6 & \\
\hline A & $4,00 \mathrm{a}$ & $15,50 \mathrm{a}$ & $27,58 \mathrm{a}$ & $39,42 \mathrm{a}$ & $52,50 a$ & $66,25 a$ & $62,25 a$ \\
\hline B & $3,83 a$ & $14,50 \mathrm{a}$ & $25,75 a$ & $37,25 a$ & $49,92 a$ & $62,83 a$ & $59,00 \mathrm{a}$ \\
\hline $\mathrm{C}$ & $4,00 \mathrm{a}$ & $15,08 \mathrm{a}$ & $26,00 \mathrm{a}$ & $37,58 a$ & $50,08 a$ & $63,83 a$ & $59,83 a$ \\
\hline D & $3,83 a$ & $14,92 \mathrm{a}$ & $25,83 a$ & $37,83 a$ & $51,00 \mathrm{a}$ & $64,67 a$ & $60,83 a$ \\
\hline
\end{tabular}

Keterangan : Angka purata yang diikuti huruf sama pada kolom sama menunjukkan tidak ada beda nyata menurut DMRT taraf nyata 5\%

A : Pembibitan pada media bibit serbuk kayu sengon

B : Pembibitan pada media bibit biji sorghum

C : Pembibitan pada media bibit biji jagung

$\mathrm{D}$ : Pembibitan pada media bibit biji padi

Hasil sidik ragam umur panen dan lama masa panen tidak beda nyata.

\section{Pembahasan}

\section{a. Pertumbuhan miselium bibit jamur tiram pada 4 bahan media pembibitan}

Panjang miselium bibit jamur tiram putih pada empat bahan media yang berbeda menunjukkan tidak berbeda pada hari ke 28, tetapi berbeda sifat miselium . Hal ini mungkin karena bahan media berbeda menunjukkan kualitas pertumbuhan miselium yang 
berbeda. Sifat miselium pada substrat biji sorghum dan biji jagung lebih tebal berwarna putih pekat, miselium pada substrat biji padi sedang dan berwarna putih, miselium pada substrat serbuk sengon tipis dan berwarna putih bening. Komposisi media pada substrat biji sorghum dan biji jagung mengandung nutrien lebih banyak untuk pertumbuhan miselium dibanding dengan substrat biji padi dan serbuk kayu sengon. Kandungan nutrien yang yang diperlukan untuk pertumbuhan jamur antara lain karbon, nitrogen, mineral dan vitamin.

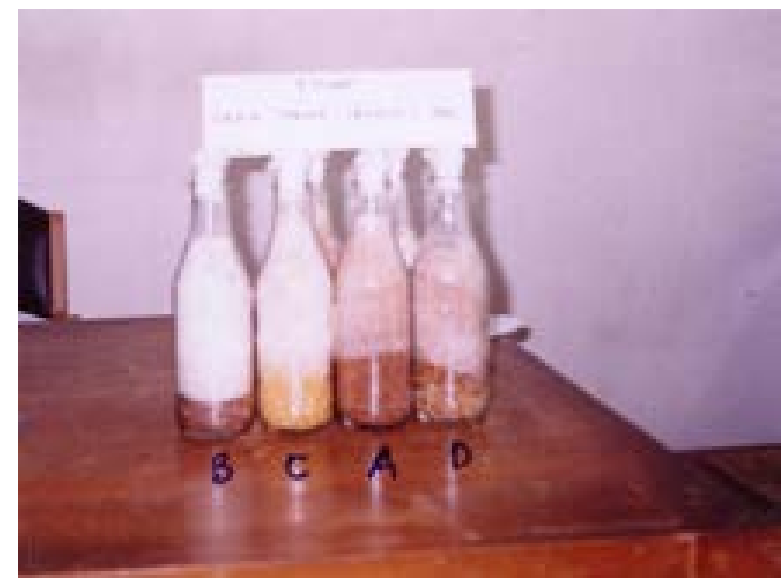

Gambar 1: Bibit jamur tiram yang telah ditumbuhi miselium (umur 21 hari) pada media bibit serbuk kayu sengon (A), biji sorghum (B), biji jagung (C), biji padi (D)

b. Pertumbuhan miselium jamur tiram putih pada 4 bahan media pembibitan

Panjang miselium pada hari ke $-7,14,21$ berbeda nyata pada beberapa bahan media pembibitan. Panjang miselium bibit jamur tiram putih pada media biji sorghum dan biji jagung lebih panjang dibanding pada media biji padi dan serbuk gergaji sengon (tabel 4). Hal ini mungkin dengan media tumbuh yang sama, tetapi berbeda media pembibitan berpengaruh terhadap panjang miselium dan saat pemenuhan miselium, karena bahan media bibit jamur tiram putih mengandung nutrisi yang berbeda untuk pertumbuhan. Kandungan nutrisi biji sorghum karbohidrat $(83 \%)$, protein $(11,0 \%)$, lemak $(3,3 \%)$, serat $(2,1 \%)$ lebih banyak dibanding dengan kandungan biji jagung. Kandungan nutrisi biji jagung meliputi karbohidrat $(68,0 \%)$, protein $(10 \%)$, lemak $(5,0 \%)$, serat $(2,0 \%)$, kandungan lain (11\%). Kandungan nutrisi biji padi meliputi karbohidrat $(76,0 \%)$, protein $(8,0 \%)$, lemak $(0,8 \%)$, serat $(1,0 \%)$, kandungan lain (11,1\%) (Nurmala, 1998) dan kandungan serbuk gergaji kayu sengon meliputi selulosa $(49,4 \%)$, lignin $(26,8 \%)$, pentosa $(15,6 \%)$ (Martawijaya, 1981).

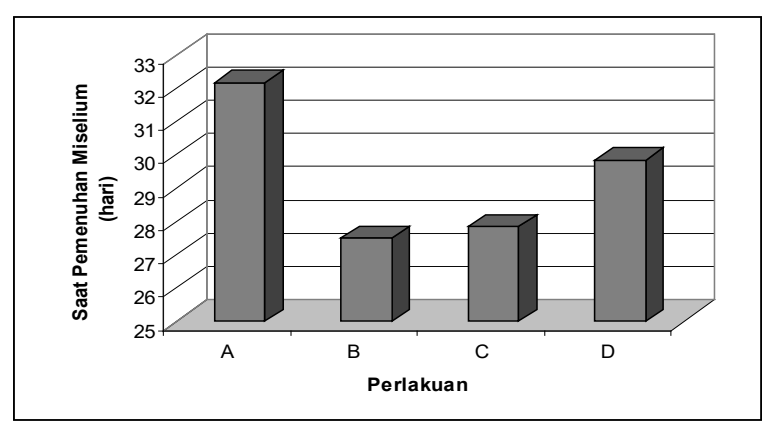

Gambar 2: saat pemenuhan miselium pada empat bahan media pembibitan 


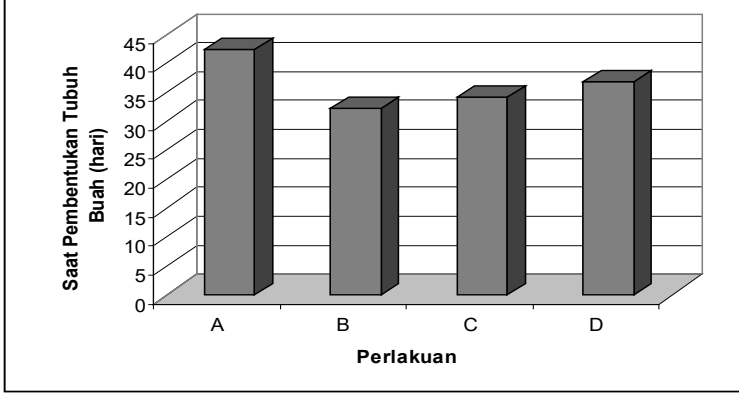

Gambar 3:saat pembentukan calon tubuh buah pada empat bahan media pembibitan

A : Pembibitan pada media bibit serbuk kayu sengon

B : Pembibitan pada media bibit biji sorghum

C : Pembibitan pada media bibit biji jagung

D : Pembibitan pada media bibit biji padi

\section{c. Hasil jamur tiram putih pada 4 bahan media pembibitan}

Saat pembentukan calon tubuh buah jamur tiram putih berbeda nyata pada empat bahan media pembibitan. Pembentukan calon tubuh buah pada perlakuan B, C dan D berbeda nyata dengan perlakuan A. Hal ini dipengaruhi oleh sifat miselium, saat pemenuhan miselium, ketersediaan nutrisi yang tersedia dalam media dan faktor lingkungan yang mendukung seperti suhu dan kelembaban. Pembentukan calon tubuh buah berlangsung setelah dilakukan pembukaan polybag setelah miselium tumbuh sampai penuh. Saat pembentukan calon tubuh buah diamati ketika muncul calon tubuh buah kecil (primordia) berukuran $\pm 1 \mathrm{~cm}$. Cepatlambatnya saat pembentukan calon tubuh buah juga sangat didukung dan dipengaruhi oleh kualitas bibit jamur yang selanjutnya akan mempengaruhi kualitas miselium dan calon tubuh buah.
Jumlah tubuh buah
dan diameter tubuh buah menunjukkan tidak beda nyata pada empat bahan media pembibitan. Halinidimungkinkan tiap polybag, jumlah tubuh buah panen tidak selalu sama. Jumlah tubuh buah tertinggi tidak selalu diikuti dengan berat segar tertinggi, begitu pula sebaliknya berat segar tertinggi tidak selalu diikuti oleh jumlah tubuh buah tertinggi. Berat segar pada perlakuan B, C dan D berbeda nyata dengan perlakuan $\mathrm{A}$. Hal ini mungkin dipengaruhi oleh sifat miselium baik menghasilkan tubuh buah yang kualitasnya baik pula dan juga dipengaruhi oleh berat media awal. Hal ini dapat dilihat dari hasil tiap panen yang menunjukkan terjadinya penurunan jumlah tubuh buah pada akhir panen, karena berat media semakin menyusut karena nutrisi dalam media berkurang dan terserap oleh miselium selama perkembangan tubuh buah, sehingga mengurangi berat media awal.

Umur panen dan lama masa panen jamur tiram putih pada empat perlakuan tidak beda nyata pada empat bahan media pembibitan . Hal ini mungkin karena media tumbuh yang digunakan adalah sama tanpa substrat tambahan dan juga dipengaruhi oleh kecepatan tumbuh miselium, saat pembentukan tubuh buah, dan jumlah tubuh buah pada setiap panen. Dalam penelitian ini panen dilakukan sebanyak enam kali, karena setelah panen 
ke enam medium jamur sudah tidak tumbuh primordia hal ini kemungkinan disebabkan oleh nutrisi media telah habis terserap oleh tubuh buah selama pertumbuhan.

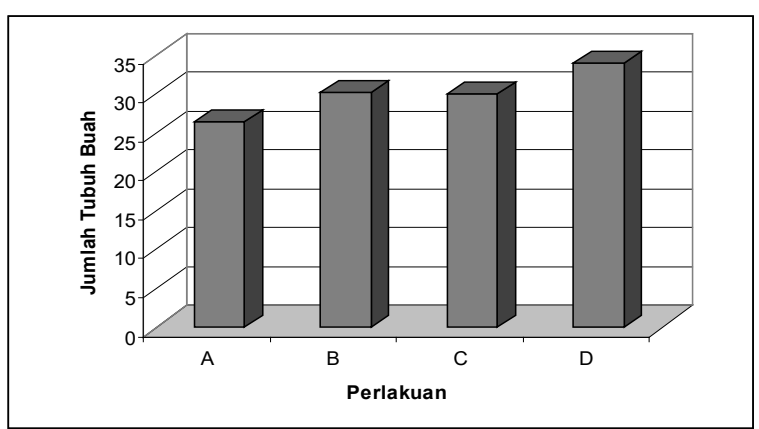

Gambar 4 :jumlah tubuh buah total pada empat bahan media pembibitan

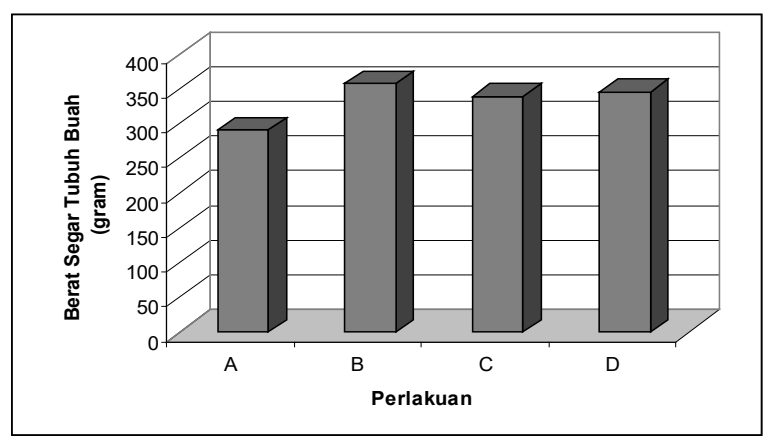

Gambar 5: berat segar tubuh buah total pada empat bahan media pembibitan
A : Pembibitan pada media bibit serbuk kayu sengon
B : Pembibitan pada media bibit biji sorghum
C : Pembibitan pada media bibit biji jagung
D : Pembibitan pada media bibit biji padi
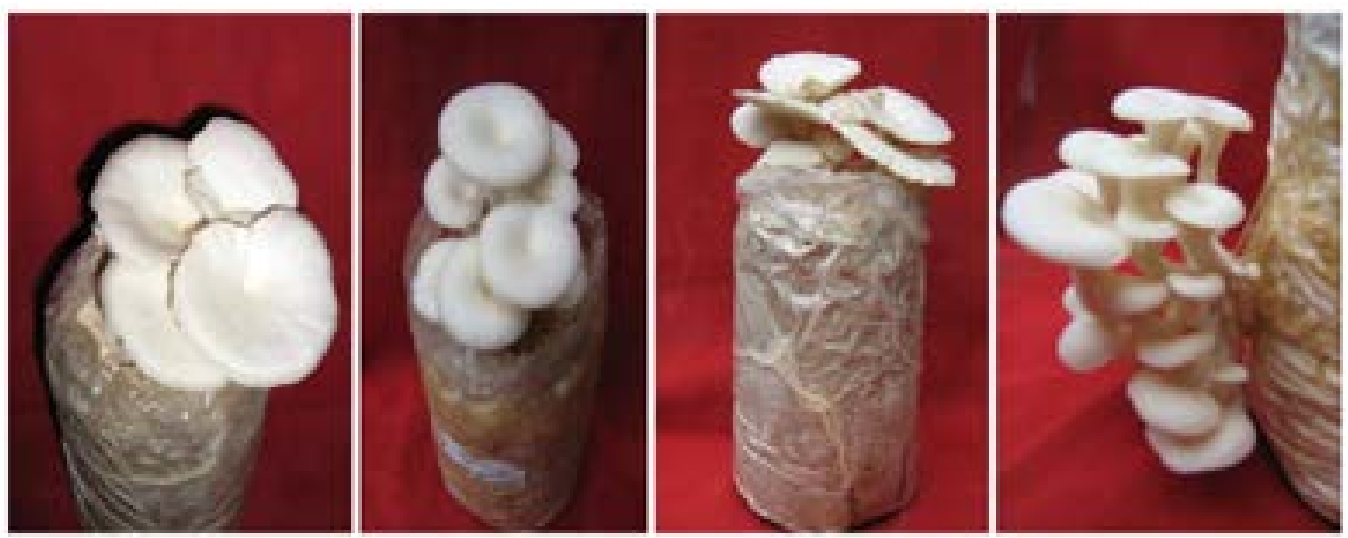

Gambar 6 : Tubuh buah siap panen pada 4 bahan media bibit(dari kiri ke kanan) : serbuk kayu sengon (1) ,biji sorghum (2), biji padi (3),dan biji jagung (4)

\section{SIMPULAN}

Berdasarkan hasil dan pembahasan maka dapat disimpulkan:

1. Media bibit biji sorghum dan biji jagung mampu mendukung peningkatan kualitas bibit jamur tiram putih yang lebih baik dari pada media biji padi dan serbuk sengon.

2. Bibit pada media substrat biji sorghum, jagung, padi, dan serbuk gergaji sengon memberikan pertumbuhan jamur tiram putih yang sama.

3. Hasil jamur tiram putih lebih baik pada bibit dengan media substrat biji sorghum, padi, jagung berturutturut.

\section{UCAPAN TERIMA KASIH}

Sahabat mba Maryati yang telah membantu dan berkontribusi dalam penelitian ini sampai selesai

\section{DAFTAR PUSTAKA}

Anonim. 1999. Tanaman Jamur Tiram ala Lembang. Trubus No. 352. Thn XXX

Anonim, 2014 https://jemberkab.go.id/ jamur-tiram-putih-tembus-pasarekspor/diakses 10 agustus 2014 
2005. RI Pasok 0,9\% Kebutuhan Jamur Dunia. http://www.nafed.go.id. diambil 04 Agustus 2006.

Atmosuseno, Budi S. 1998. Budidaya, Kegunaan, dan Prospek Sengon. Penebar Swadaya. Jakarta. 40 hal.

Cahyana, YA., Muchroji, dan M Bakrun. 2002. Jamur Tiram. Penebar Swadaya. Jakarta. 63 hal.

2005. Jamur Tiram; Pembibitan, Pembudidayaan, Analisis Usaha. Penebar Swadaya. Jakarta. 64 hal.

Djarijah, Nunung M, dan Abbas Siregar D. 2001. Jamur Tiram, Pembibitan, Pemeliharaan, dan Pengendalian HamaPenyakit. Kanisius. Yogyakarta. 67 hal.

Gunawan, Agustin Wydia. 2005. Usaha Pembibitan Jamur. Penebar Swadaya. Jakarta. 112 hal.
Lubis, D A., 1992. Ilmu Makan Ternak. PT. Pembangunan. Jakarta. 203 hal.

Martawijaya, A. 1981. Atlas Kayu Indonesia. Balai Penelitian Hasil Hutan. Bogor.

Nurmala, Tati. 1998. Serealia Sumber Karbohidrat Utama. PT Rineka Cipta. Jakarta. 93 hal.

Reginawati, 1999. Produksi Jamur Menurun. www.kpel.or.id. diambil 6 April 2006.

Soenanto, Hardi. 2000. Jamur Tiram, Bididaya dan Peluang Usaha. Aneka Ilmu. Semarang. 24 hal.

Suriawiria, H Unus. 2002. Budidaya Jamur Tiram. Kanisius. Yogyakarta. 87 hal. . 2004. Sukses Beragrobisnis Jamur Kayu: Shiitake, Kuping, Tiram. Penebar Swadaya. Jakarta. 104 hal. 